\title{
УДК 342.4
}

DOI https://doi.org/10.24144/2307-3322.2021.65.13

\section{ПОНЯТТЯ ТА ФОРМИ ВЗАЕМОДІЇ СУБ'ЄКТІВ ПРАВА В АСПЕКТІ КОНСТИТУЦИЙНӦ̈ ЕКОНОМІКИ}

\author{
О.В. Приходько, \\ аспірантка Науково-дослідного \\ інституту державного будівництва та місиевого \\ самоврядування НАПрН України \\ ORCID : 0000-0002-5748-9009 \\ lena@modelex.mc
}

Приходько О.В. Поняття та форми взаємодії суб'єктів права в аспекті конституційної економіки.

У статті досліджується актуальна як для правової науки так і практики проблема взаємодії суб'єктів економічних відносин в аспекті конституційної економіки.

Зазначається, що в науковій доктрині $є$ різні підходи до розуміння терміну взаємодія. Різні вчені підкреслюють особливості взаємодії як певного процесу та надають свої визначення взаємодії. Враховуючи предмет дослідження конституційної економіки запропоновано авторське визначення цього явища.

Підкреслюється, що маючи в економічних відносинах групу суб'єктів, що наділені владними управлінськими функціями, а також приватних суб'єктів, їх взаємодія покликана задовольняти одночасно як суспільний, так і приватний інтереси.Учасники перебувають між собою у горизонтальних відносинах, а не у відносинах влади і підпорядкування. Взаємодія владних і невладних суб'єктів направлена на досягнення чітко визначеної мети, зокрема встановлення або зміна правового регулювання певних економічних відносин, досягнення певних економічних результатів, здійснення економічних реформ, вирішення соціально-економічної проблеми тощо.

На прикладі правової дійсності України запропоновано розглянути деякі з форм взаємодії суб'єктів вітчизняної економіки, що активно використовуються в нашій державі. Так, зазначається, що поширеною формою взаємодії влади та бізнесу є створення дорадчих органів та робочих груп, до складу яких входять як представники органу державної влади, так і представники громадянського суспільства і бізнесу.

Відзначається, що поширеною в світі формою співпраці є лобізм, однак в Ураїні відсутнє законодавство про лобістську діяльність, а зареєстровані в парламенті законопроекти мають суттєві недоліки.

Одним із найбільш успішних моделей взаємодії влади та бізнесу визначено державно-приватне партнерство, яке допомагає досягти синергії та реалізовувати масштабні проекти у різних сферах економіки, в тому числі соціального характеру, починаючи від будівництва доріг і закінчуючи освоєнням космічного простору.

В якості форми конструктивної взаємодії влади та бізнесу також названо соціальну відповідальність підприємців.

Ключові слова:конституційнаекономіка, взаємодія, лобізм, партнерство, соцальнавідповідальність

Prykhodko O.V. Definitions and forms of interaction of legal entities in the aspect of constitutional economics.

The article investigates the problem of interaction of subjects of economic relations in the aspect of constitutional economics, which is relevant for both legal science and practice.

It is noted that in scientific doctrine there are different interpretations of the term interaction. Various scientists emphasize the specificities of an interaction as a certain process andprovide their own definitions of interaction. Given that the subject of this study is constitutional economics, the author's definition is proposed.

It is important to highlight, that if an economic relationshipinvolves a group of subjects endowed with state functions, on the one hand,and private entities, on the other,then their interaction is designed to satisfy both public and private interests. The participants are in a horizontal relationship with each other, not in a relationship of power and subordination. The interaction of governmental and non-governmental actors is aimed at achieving a clearly defined goal, including the establishment or change of legal regulation of certain economic relations, achieving certain economic results, implementing economic reforms, solving socio-economic problems, etc. 
Taking the Ukrainian legal reality into consideration, it is proposed to analyse some forms of interaction within the domestic economy, which are actively used in our country. Thus, it is noted that a common form of interaction between government and business is the creation of advisory bodies and working groups, which include both representatives of public authorities, civil society and business.

It is noted that lobbying is a common form of public-private cooperation in the world, but there is no legislation on lobbying in Ukraine, and bills registered in parliament are characterised by significant shortcomings.

One of the most successful models of interaction between government and business is public-private partnership, which helps to achieve synergies and implement large-scale projects in various sectors of the economy, including social, from road construction to space exploration.

The social responsibility of entrepreneurs is also mentioned as a form of constructive interaction between government and business.

Key words: constitutional economics, interaction, lobbying, partnership, social responsibility.

Постановка проблеми. Розвиток економічних процесів в рамках встановлених Конституцією України засад передбачає виникнення різних форм взаємовідносин між суб'єктами економічних взаємовідносин. Найбільш продуктивнми з точки зору зростання економічного добробуту держави взаємовідносинами між суб'єктами, що впливають на економіку, є їх взаємодія.

Водночас, на науковому рівні проблематика взаємодії суб'єктів права з точки зору конституційної економіки досліджувалось не достатньо. Таке дослідження $є$ актуальним як з підходів наукової доктрини, так $\mathrm{i}$ зважаючи на його важливість для практики.

Метою статті $\epsilon$ з'ясування поняття взаємодії суб'єктів економічних відносин з точки зору конституційної економіки, визначення мети такої взаємодії, розкриття форм взаємодії в реаліях української правової системи.

Виклад основного матеріалу. поняття взаємодія носить філософський характер. Проте якщо відносини «причина-наслідок» носять односторонній характер, взаємодія є відношенням, в якому причина і наслідок не є константами, а перебувають у стані постійної взаємозаміни.

«Взаємодією» є зустрічний вплив кількох явищ, їх взаємний зв'язок.

О.Кваша зазначає, що категорія взаємодії є фундаментальною, ключовою для глибокого та конструктивного розуміння інших категорій, таких як «рух», «детермінація», «причина», «зв'язок», «вплив», «дія» та ін. Категорії «причина» i «дія» логічно відтворюють один з моментів руху і взаємодії речей на сутнісному рівні. Причина, переходячи в дію, відроджується у ній і навпаки. У цьому взаємному обумовленні причина i дія зливаються у взаємодію; однонаправлена детермінація переходить в симетричну, взаємну детермінацію. Відповідно, речі виступають одночасно як активні та пасивні, діють зовні і як такі, що відчувають дію на собі, як рушійні та приведені в рух (але в різних взаємозв'язках) [1].

На думку М. Марченка, головна риса взаємодії - взаємні зміни явищ, які не пасивно співвідносяться між собою, а впливають одне на одне. «Причино-наслідкова залежність» припускає породження, «виробництво» одного явища іншим, це поняття виражає односторонність впливу, є доповнюючим до поняття взаємодії. М.Марченко виділяє наступні зв'язки взаємодії: а) породження; б) перетворювання; в) розвиток [2].

Соціальна «взаємодія» у соціології розглядається як процес безпосереднього чи опосередкованого впливу соціальних об'єктів один на одного, під час якого сторони, що взаємодіють, пов'язані циклічною причинною залежністю. Соціальна взаємодія, як вид зв 'язку, об'єднує у собі інтегрованість дій, функціональну координацію їх наслідків, тобто постає системою дій, що обумовлює засоби реалізації спільної діяльності, а також є підставою суспільної солідарності [3].

На нашу думку категорія взаємодії не містить єдиного усталеного розуміння та може мати особливості в різних наукових дисциплінах та сферах суспільного життя. Проте враховуючи ключові спільні підходи до розуміння взаємодії під взаємодією суб'єктів права в аспекті конституційної економіки пропонується розуміти таке взаємовідношення між суб'єктами економічних відносин, предметом якого $є$ їхній взаємний вплив з метою забезпечення економічного зростання, а також гарантування та забезпечення економічних конституційних прав і свобод.

Сучасне українське суспільство і держава знаходяться в пошуку найбільш ефективних форм взаємодії з підприємцями. Цей соціальний прошарок суспільства також проходить становлення як найважливіший економічний інститут життєзабезпечення суспільства. Його повноцінне функціонування в економічному просторі держави можливе тільки за наявності сформованого інституту взаємодії з владними органами [4].

В.Смельянов, досліджуючи взаємодію влади та бізнесу, виділяє три форми партнерства між ними:

1) економічне партнерство (спільна підприємницька діяльність державних та приватних структур); 
2) правове партнерство (спільні робочі групи щодо вдосконалення законодавства про підприємницьку діяльність);

3) організаційне партнерство (різні форми участі представників однієї із сторін у структурних підрозділах інших і навпаки) [5].

Досліджуючи дефініцію взаємодії суб'єктів економічних відносин необхідно розкрити систему ознак, притаманних цьому явищу.

1. Взаємодія передбачає активну форму діяльності декількох суб’єктів. Будь-яка діяльність лише одного суб'єкта, якою б ефективною та економічно доцільною вона не була, не може розглядатися як взаємодія.

2. Хоча суб'єкти економічних відносин можуть мати суто внутрішньо-групову взаємодію (узгоджені дії, картельні змови, етичні стандарти ринку тощо) в аспекті цього дисертаційного дослідження в якості взаємодії суб'єктів економічних взаємовідносин пропонується розглядати саме взаємодію владних і невладних суб'єктів між собою.

3. Взаємодія суб'єктів з точки зору конституційної економіки передбачає, що ії учасники перебувають між собою у горизонтальних відносинах, а не у відносинах влади і підпорядкування.

4. Взаємодія є процесом, що передбачає взаємний вплив. Як процес взаємодія може мати певну тривалість, етапи, стадії тощо.

5. Взаємодія направлена на досягнення чітко визначеної мети. Такою метою може бути встановлення або зміна правового регулювання певних економічних відносин, досягнення певних економічних результатів, здійснення економічних реформ, вирішення соціально-економічної проблеми тощо.

На прикладі правової дійсності України пропонується розглянути деякі з форм взаємодії суб’єктів вітчизняної економіки, що активно використовуються в нашій державі.

Доволі поширеною формою взаємодії влади та бізнесу є створення дорадчих органів та робочих груп, до складу яких входять як представники органу державної влади, так і представники громадянського суспільства і бізнесу. Довгий час практично при кожному органі державної влади функціонувала громадська рада. Хоча реального впливу на діяльність суб'єкта владних повноважень такі утворення здебільшого не мали, проте створювали у громадського сектору відчуття долученості.

Більш ефективними себе показали робочі групи, які сфокусовані на конкретній проблематиці, та до складу яких включені учасники певного ринку, на який матиме вплив результат роботи такої групи.

До прикладу на сьогоднішній день при Міністерстві економіки України створено офіс розвитку малого і середнього підприємництва в якості постійно діючого консультативно-дорадчого органу при Міністерстві. Метою цього органу є сприяння виконанню завдань, визначених планом заходів з реалізації Стратегії розвитку малого і середнього підприємництва в Україні.

Іншим прикладом взаємодії Міністерстві економіки України з представниками бізнес-спільноти є Координаційна рада 3 питань розвитку мікро- та малого підприємництва, яка створена та функціонує при Міністерстві. До складу ради входять представники всіх ключових міністерств економічного блоку Уряду. Від бізнес-спільноти до Координаційної ради з питань розвитку мікро- та малого підприємництва представлена входить Українська Рада Бізнесу, Українська асоціації прямого продажу, Асоціація «IT Ukraine», Громадська спілка «Національна організація роздрібної торгівлі», Національна бізнес коаліція, Всеукраїнська асоціація органів місцевого самоврядування «Українська асоціація районних та обласних рад», Український союз промисловців і підприємців, Спілка Українських Підприємців, Громадська організація «Самозахист підприємців», Громадська спілка «МейдінЮкрейн», Громадська організація «Всеукраїнське об’єднання підприємців малого та середнього бізнесу «Фортеця», Громадська спілка «Національна платформа малого та середнього бізнесу», Асоціація платників податків України, Громадська спілка «Українська міжнародна бізнес асоціація» та інші.

В окремих випадках робочі групи не створюються, проте процедура підготовки проекту регуляторного акта передбачає обов'язкову стадію обговорення з представниками підприємців, яких стосуватиметься той чи інший акт. Зокрема на офіційному веб-сайті Кабінету Міністрів України розміщено орієнтовний календарний графік консультацій з громадськістю на 2021 рік в розрізі кожного міністерства та органу державної виконавчої влади.

У такому графіку зазначається, приміром, що проект Закону України «Про внесення змін до Закону України «Про виноград та виноградне вино» буде обговорено на онлайн засіданні робочої групи з питань сприяння розвитку галузі виноградарства та виноробства у форматі Zoom-конференції, зазначено орієнтовні строки проведення цього засідання та контакти відповідального представника міністерства; проект Закону України щодо захисту прав інтелектуальної власності, а також проект наказу Мінекономіки «Про затвердження Правил складання та подання заявки на промисловий зразок» розглядатимуться у вересні 2021 року 
шляхом електронні консультацій із залучення зацікавлених осіб різних сфер ринку.

Подібний підхід дозволяє більш точково налагодити взаємодію з метою підготовки проектів конкретних рішень та актів, які мають суттєве значення для певного сегмента національної економіки, а також врахувати думку та пропозиції підприємців, які здійснюють діяльність на відповідному ринку.

Не завжди підприємці мають можливість безпосередньо співпрацювати з представниками органів державної влади, відстоюючи свої права та законні інтереси. Для цього може бути не достатньо часу, ресурсів, компетенції. Саме тому, однією з найбільш поширених форм взаємодії учасників ринку та органів влади в розвинутих країнах світу є лобізм.

Поняття «лобізму» виникло в другій половині XIX століття у США та Великій Британії. Лобізм як процедура чітко унормована законодавчо, але регулювання в різних країнах може відрізнятись. У США лобісти мають офіційно реєструватись та визначати сферу своїх інтересів, а також подавати регулярні звіти. Законодавство щодо лобіювання існує також у шести державах-членах ЄС: Австрії, Ірландії, Словенії, Франції, Польщі і Литві.

Як слушно зазначає В. Биковець, лобізм у значній мірі сприяє формуванню стійкого «балансу сил» у суспільстві, який створюють групи інтересів. Останні, у свою чергу, віддзеркалюють думку значних верств населення. Отже, діяльність груп політичних інтересів сприяє досягненню політичного консенсусу в суспільстві. Вона дає уявлення політикам і співробітникам державних структур про широкий спектр суспільних потреб і думок більшості груп інтересів[6].

М.Росенко вказує на те, що цілі лобізму різноманітні. Проте навіть в країнах з багатими демократичними традиціями лобізм переслідує переважно соціально-економічні цілі, пов'язані з вирішенням питань власності і прав розпорядження нею; наданням прав на ведення конкретної діяльності; державним замовленням; квотами, ліцензіями; дотаціями, кредитами; тарифами на енергоресурси; економічними і податковими пільгами; фінансуванням соціальних програм тощо [7].

Дійсно, лобізм є частиною політичної системи України, проте він носить в більшості випадків виключно тіньовий характер. В Україні декілька разів робилися спроби законодавчого врегулювання лобістської діяльності. На сьогоднішній день в парламенті зареєстровано одразу 4 законопроекти, якими пропонується регулювати вітчизняний лобізм.

Хоча актуальність нормативного врегулювання взаємодії бізнесу та влади через інститут лобізму не викликає сумніву, запропоновані законопроекти викликають критику у представників громадянського суспільства. Зокрема, низка громадських організацій, членів ініціативи «Реанімаційний пакет реформ», у спільному листі зазначають, що закладені в цих законопроектах положення, несуть загрозу обмеження прав громадян та організацій громадянського суспільства для здійснення і захисту своїх прав і свобод, задоволення своїх громадянських, економічних, соціальних, культурних та інших інтересів, а також право на участь у виробленні рішень органів державної влади та органів місцевого самоврядування, гарантованих ст. 5 і 36 Конституції України, ст. 21 Закону України «Про громадські об'єднання», іншими законами України, а також ст. 25 ратифікованого Україною Міжнародного пакту про громадянські і політичні права. Системним недоліком цих законопроектів є намір поширити регулювання лобізму на гарантовану законами діяльність організацій громадянського суспільства і громадян, спрямовану на реалізацію своїх прав та інтересів через участь у формуванні публічної політики.У названих законопроектах немає чіткого визначення лобізму як виду комерційної діяльності, яка передбачає надання суб'єктом підприємницької діяльності послуг із реалізації інтересів замовника в рішеннях/нормативно-правових актів органів влади. Виключно діяльність, яка підходить під це обмежене визначення лобізму, може бути предметом законодавчого регулювання [8].

Дійсно, якщо проаналізувати наведені законопроекти щодо регулювання лобістської діяльності можна відмітити, що ця діяльність недостатньо чітко відмежована від діяльності, яку здійснюють громадські організації, спілки, об’єднання та інші організації громадянського суспільства. Відповідно до одних законопроектів занадто широкий перелік суб’ єктів може попасти під визначення лобістської організації, що покладатиме на них непропорційно обтяжливі зобов'язання. Відповідно до інших навпаки лобістська діяльність буде настільки жорстко регламентована, що практично позбавить громадські об'єднання здійснювати будьякий вплив на порядок денний формування публічної політики.

Одним із найбільш успішних моделей взаємодії влади та бізнесу, що практикується в світі, є державно-приватне партнерство. Державно-приватне партнерство допомагає досягти синергії та реалізовувати масштабні проекти у різних сферах економіки, в тому числі соціального характеру, починаючи від будівництва доріг і закінчуючи освоєнням космічного простору.

В Україні державно-приватне партнерство теж має свою правову регламентацію у спеціальному Законі України «Про державно-приватне партнерство». Відповідно до вказаного закону державно-приватним 
партнерством вважається співробітництво між державою та юридичними особами, крім державних та комунальних підприємств, установ, організацій (приватних партнерів), що здійснюється на основі договору в порядку, встановленому цим Законом та іншими законодавчими актами, та відповідає ознакам державно-приватного партнерства, визначеним цим Законом.

Законодавець, формулюючи дефініцію державно-приватного партнерства, зробив акцент на визначенні суб'єктного складу цих відносин та сформулював перелік суб'єктів, які можуть виступати державним партнером. Укладення договору в рамках державно-приватного партнерства здійснюється на конкурсних засадах. Законодавець також вказав, що партнерство здійснюється на договірних засадах і повинно відповідати визначеним ознакам.

Так, до ознак державно-приватного партнерства належать такі:

1) створення та/або будівництво (нове будівництво, реконструкція, реставрація, капітальний ремонт та технічне переоснащення) об’ єкта державно-приватного партнерства та/або управління (користування, експлуатація, технічне обслуговування) таким об'єктом;

2) довготривалість відносин (від 5 до 50 років);

3) передача приватному партнеру частини ризиків у процесі здійснення державно-приватного партнерства;

4) внесення приватним партнером інвестицій в об'єкт державно-приватного партнерства.

Законом передбачається декілька форм, у яких може здійснюватись державно-приватне партнерство: концесія, управління майном, спільна діяльність.

Тривалий час механізм державно-приватного партнерства фактично не працював за виключенням поодиноких випадків. Бізнес намагався уникати словосполучення державно-приватне партнерство, укладаючи 3 органами державної влади різні види договорів, які за своєю сутністю мали б розглядатись саме як договори державно-приватного партнерства. Таким підходом, зокрема, керувалися в галузі житлового будівництва, коли забудовувались земельні ділянки державних підприємств та міністерств.

Проте останні роки в Україні з'являється все більше прикладів укладення великих договорів державно-приватного партнерства. Цьомусередіншогосприялоухвалення нового Закону України «Про концесії».

Слід особливо відмітити 2020 рік. 22.12.2020 року було укладено Меморандум про взаєморозуміння і співробітництво з компанією концесіонера QTerminals W.L.L щодо передачі в концесію строком на 35 років спеціалізованого порту «Ольвія» в Миколаєві. Всього за 35 років концесії буде залучено до 17,3 млрд грн інвестицій. QTerminals управляєнайбільшим торговим портом Катару.

Також у 2020 році у концесію передали Херсонський морський торговельний порт. Компанія-концесіонер ТОВ «Рисоіл-Херсон» повинна інвестувати у розвиток порту близько 300 млн грн.

В якості форми конструктивної взаємодії влади та бізнесу слід також назвати соціальну відповідальність підприємців. Тенденція розвитку бізнесу пов'язана з тим, що в його діяльності економічна результативність пов'язується з соціальною практикою, його співучастю в суспільно значущих проектах. Це обумовлює зміну характеру взаємовідносин між бізнес-структурами, державою і суспільством: по-перше, соціальна діяльність бізнесу сприяє зняттю напруженості у взаєминах, формуванню більшої довіри до нього з боку держави і суспільства; по-друге, вона створює передумови для підвищення якості життя людей, що формує потенціал для зниження конфліктності у суспільстві [9].

2020-2021 роки в Україні дали безліч прикладів, коли бізнес за власної ініціативи долучався до допомоги державі, особливо у зв'язку з потребою долати виклики корона кризи. Це, зокрема, придбання медичного обладнання, препаратів, засобів індивідуального захисту, ремонти медичних установ, фінансування фондів по боротьбі з ковідом тощо.

Таким чином, з точки зору конституційної економіки ефективна взаємодія суб'єктів економічних взаємовідносин є якісною характеристикою економіки в державі та ключовою умовою їі укріплення та зростання.

Висновки. Підсумовуючи, можна сказати, що економічне зростання безпосередньо пов'язане з ефективною взаємодією державних та приватних суб' єктів економічних відносин. На науковому рівні не напрацьовано єдиного розуміння категорії взаємодії Пропонується авторське визначення взаємодії суб'єктів права в аспекті конституційної економіки під якою пропонується розуміти таке взаємовідношення між суб' єктами економічних відносин, предметом якого є їхній взаємний вплив з метою забезпечення економічного зростання, а також гарантування та забезпечення економічних конституційних прав і свобод.

Пропонується виділити такі форми взаємодії суб'єктів конституційної економіки України: створення дорадчих органів та робочих груп при суб' єктах владних повноважень; проведення консультацій з громадськістю як етапу підготовки проектів нормативно-правових актів; лобіювання; державно-приватне партнерство; соціальна відповідальність бізнесу. 


\section{Список використаних джерел:}

1. Кваша О.В. Зміст і значення понять «взаємодія» та «система» у філософських і правових досліджень. URL: http://dspace.nbuv.gov.ua/bitstream/handle/123456789/64055/06-Kvasha.pdf?sequence=1

2. Марченко М.Н. Проблеми теории государства и права. -Москва: Юристь, 2001. 642c.

3. Ярмак О.М. Поняття, сутність взаємодії та її роль у розвитку соціальної системи.URL: http://old.pb.univd.edu. ua/?controller=service\&action=download\&download=18856

4. Форми взаємодії держави та бізнесу в аграрній сфері України: інституційний аспект. Аналітична записка. URL:https://niss.gov.ua/doslidzhennya/ekonomika/formi-vzaemodii-derzhavi-ta-biznesu-v-agrarniy-sferi-ukraini-instituciyniy

5. Ємельянов В.М. Взаємодія між органами влади на регіональному та державному рівнях щодо розвитку бізнессередовища. Економіка та держава. 2008. № 8. С.107-109.

6. Буковець В. Лобізм у системі представництва інтересів. URL:https://ipiend.gov.ua/wp-content/uploads/2018/07/ bykovets_lobizm.pdf

7. Росенко М.І. Лобізм і його роль в діяльності сучасних парламентів. Шляхи удосконалення регламентації діяльності лобістів в парламенті України. URL: http://www.dy.nayka.com.ua/?op=1\&z=214

8. Заява організацій громадянського суспільства щодо законопроєктів про лобізм в Україні. URL:https://rpr.org.ua/ news/zaiava-orhanizatsiy-hromadians-koho-suspil-stva-shchodo-zakonoproiektiv-pro-lobizm-v-ukraini/

9. Бержанір А.Л. Становлення взаємодії влади, бізнесу і суспільства в ринкових умовах. URL: http://www. irbis-nbuv.gov.ua/cgi-bin/irbis_nbuv/cgiirbis_64.exe?C21COM=2\&I21DBN=UJRN\&P21DBN=UJRN\&IMAGE_FILE_ DOWNLOAD=1\&Image_file_name=PDF/sre_2013_3_5.pdf 